\title{
DETERMINATION OF ACTINIDES IN URINE \\ BY LIQUID ION EXCHANGE
}

F. E. Butler

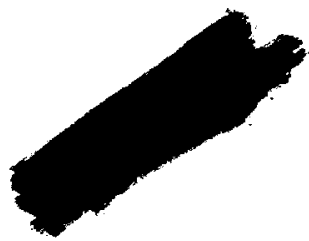

Savannah River Plant

E. I. du Pont de Nemours and Company

Aiken, South Carolina

August 1963

Prepared for presentation at the October 1963 Bio-Assay and Analytical Chemistry Conference in San Diego, California.

The information contained in this article was developed during the course of work under contract AT(07-2)-1 with the U.S. Atomic Energy Commission. 


\section{Determination of Actinides In Urine By Liquid Ion Exchange}

\section{Introduction}

The need for analytical methods to determine the actinides separately, and as mixtures, will increase as production of the transplutonium elements increases.

Iiquid ion exchange is a relatively new technique for the chemical analysis of urine samples. In this method an aqueous sample is extracted with an exchanger dissolved in an inert solvent. Nuclides as anions and cations are substituted at exchange sites in the liquids similar to absorption by solid ion exchangers ${ }^{1}$. An advantage of liquid ion exchange is the rapidity of both absorption and desorption of ions.

Anion and cation exchange reactions used to separate the alpha-emitting actinides $\mathrm{Th}, \mathrm{Np}, \mathrm{U}, \mathrm{Pu}, \mathrm{Am}$, and $\mathrm{Cm}$, are described in this paper. Methods of analyzing urine for specific actinides are presented.

\section{Discussion}

\section{Liquid Exchangers Tested}

Three exchangers were used in experiments. One was di-2-ethylhexyl phosphoric acid (HDEHP), an acidic cation exchanger. The others were tri-isooctylamine (TIOA) and "Alamine-336," both tertiary amines which function as anion exchangers. Because preliminary experiments showed that the amine extractions gave similar results, only TIOA will be discussed here.

\section{Screening Experiments with Aqueous Solutions}

The actinides were separated initially with solutions containing various concentrations of $\mathrm{HNO}_{3}$ and $\mathrm{HCl}$. Samples were spiked and small aliquots were counted for alpha or gamma activity, before and after extraction. Similar tests were made to strip the actinides from the organic phases. 
Conditions were sought for quantitative separation of a specific actinide with good decontamination for the other nuclides. Some of the variables studied were:

- Concentrations of exchangers in inert solvents.

- Volume ratios of the sample, organic, and stripping solutions.

- Acidity of the sample solutions.

- Contact times of the solutions.

- Valences of the actinides.

\section{Analysis of Urine}

When analytical methods using aqueous solutions showed promise, additional tests with urine samples were made. Samples were prepared for analysis by wet ashing (oxidizing) them to a white residue. Initially, composite urine samples up to $250 \mathrm{ml}$ were analyzed. Separation procedures were finally tested with individual samples. The valences of the actinides in the wet oxidized urine samples were not adjusted except for the Np and Pu procedures.

\section{Exchange with TIOA}

Slide 1 shows extractions of aqueous sample solutions with $10 \%$ TIOA in xylene. All extraction times were one minute and equal volumes of sample and organic solutions were used. Only uranium was exchanged almost completely from 3N HCl solution; both Np and Pu were extracted at higher $\mathrm{HCl}$ concentrations. Th, $\mathrm{Am}$, and $\mathrm{Cm}$ did not form exchangeable anionic complexes with $\mathrm{HCl}$. Th, Np, U, and Pu were partially exchanged from $4 \mathrm{~N} \mathrm{HNO}_{3}$.

ENRICHED URANIUM

Other tests were made to determine the best solution for extracting $\mathrm{U}^{235}$ absorbed in $75 \mathrm{ml}$ of $10 \%$ TIOA-xylene. Two successive one-minute extractions with $20 \mathrm{ml}$ of distilled water removed $88 \%$ and $12 \%$ of the $\mathrm{U}^{235}$. 
Experiments with urine samples resulted in the following procedure (Slide 2). Urine was wet ashed to a white residue and dissolved in $50 \mathrm{ml}$ of $3.5 \mathrm{~N} \mathrm{HCl}$. The sample was extracted in a separatory funnel for 2 minutes with $50 \mathrm{ml}$ of $10 \%$ TIOA-xylene. It was then transferred to a second funnel and extracted with $25 \mathrm{ml}$ of $10 \%$ TIOA-xylene. Organic phases were combined and washed with $15 \mathrm{ml}$ of $3.5 \mathrm{~N} \mathrm{HCl}$, which was discarded. The wash solution removed traces of urine salts and other actinides. $\mathrm{U}^{235}$ was then stripped from the TIOA with two 25-ml volumes of distilled water. The water was evaporated, and the residue was plancheted and counted.

Final planchets contained less than $5 \mathrm{mg}$ of solids, and recoveries of $\mathrm{U}^{235}$ spikes at levels down to $10 \mathrm{~d} / \mathrm{m}$ per sample were greater than $95 \%$. Decontamination factors for other actinides were greater than 1000 . Total preparation time after dissolution of the oxidized urine salts was less than one hour per sample.

\section{NEPTUNIUM AND PLUTONIUM}

Slide 1 also shows some extraction of $\mathrm{Np}$ and $\mathrm{Pu}$ from $\mathrm{HNO}_{3}$ solution to TIOA-xylene. Tests indicated that valence adjustments were necessary for complete exchange of the two actinides. Pu (III) will not exchange, but Np (IV), Pu (IV), and Pu (VI) will exchange to TIOA ${ }^{2}$. Slide 3 shows three ways to extract $\mathrm{Np}$ or $\mathrm{Pu}$. Ammonium iodide reduced plutonium to $\mathrm{Pu}$ (III) which was not extracted from concentrated HCl, but more than $99 \%$ of $\mathrm{Np}$ (IV) was extracted. This procedure could not be used for urine, however, since the salts will not dissolve in concentrated HCl. Ferrous ammonium sulfate resulted in exchange of more than 95\% Pu from $2 \mathrm{~N} \mathrm{HNO}_{3}$, with less than $5 \% \mathrm{~Np}$ exchange.

Ferrous sulfamate reduction was the most promising method for extracting Np (IV) from a urine sample. When this procedure for Np is preceded by the U procedure, a good decontamination factor is obtained for each of the other actinides, with the exception of Th. 
After removal of $\mathrm{Np}$ from the sample solution, the Pu (III) was oxidized by heating and addition of more $\mathrm{HNO}_{3}$. The $\mathrm{Pu}$ (IV) and $\mathrm{Pu}$ (VI) were then exchanged to a separate solution of TIOA-xylene. Both Np and Pu were stripped from organic solution with distilled water.

\section{Exchange with HDEHP}

Slide 4 shows extractions with aqueous sample solutions and 20\% HDEHPtoluene. More than $90 \%$ of the Th, Np, U, and Pu were exchanged from $4 \mathrm{~N} \mathrm{HNO}_{3}$, and none of the $\mathrm{Am}$ or $\mathrm{Cm}$ was exchanged. By contrast, greater than 99\% of the Am and $\mathrm{Cm}$ were exchanged from distilled water solutions $(\mathrm{pH} 4-5)$.

\section{AMERICIUM AND CURIUM}

The urinary $\mathrm{Am}$ and $\mathrm{Cm}$ procedure is as follows (Slide 5). A sample is prepared in $4 \mathrm{~N} \mathrm{HNO}_{3}$ and extracted into $20 \% \mathrm{HDEHP}-$ toluene to remove $\mathrm{Th}$, $\mathrm{Np}, \mathrm{U}$, and $\mathrm{Pu}$. The aqueous solution is then neutralized with $\mathrm{NH}_{4} \mathrm{OH}$, and $\mathrm{Am}$ and $\mathrm{Cm}$ are exchanged to a fresh solution of HDEHP-toluene. Data in Slide 6 indicate that more than 95\% Am was exchanged from a solution of oxidized urine when the equilibrium $\mathrm{pH}$ was between 3.7 and 5.1 ( $\mathrm{pH}$ after extraction), and greater than 99\% Am was exchanged at equilibrium pH 4.5 . $\mathrm{pH}$ control is not critical enough to require instrument measurement for each sample, but can be satisfactorily achieved by adding consistent quantities of reagents. More than 95\% of the Am and $\mathrm{Cm}$ present can be removed from solutions of urine in this way. Am and $\mathrm{Cm}$ were then stripped from the organic solution with $4 \mathrm{NHNO}_{3}$. The acid was evaporated, and the residue was plancheted and counted.

\section{Work in Progress}

These liquid ion exchange procedures yield solutions suitable for electrodeposition of very small amounts of the actinides. Future work will include attempts to improve electrodeposition techniques so that detection limits will be lower than those possible by direct alpha counting. 


\section{References}

1. Coleman, D. F., C. A., Blake, Jr., and K. B., Brown, Talanta 9, 297-323 (1962).

2. Schneider, R. A., Anal. Chem. 34, 522-525 (1962).

The information contained in this article was developed during the course of work under contract AT(07-2)-1 with the U. S. Atomic Energy Commission. 


\begin{tabular}{|c|c|c|c|c|c|c|}
\hline \multirow[b]{2}{*}{ AQUEOUS SOLUTION } & $\begin{array}{l}\text { INIDE } \\
\% \mathrm{~T}\end{array}$ & $\begin{array}{l}S E \\
\partial A-X\end{array}$ & $\begin{array}{l}\text { TRA } \\
\text { ILE }\end{array}$ & $\begin{array}{l}\text { CTE } \\
\text { VE }\end{array}$ & D INT & \\
\hline & $\mathrm{Th}^{232}$ & \multicolumn{4}{|c|}{ PERCENT EXTRACTED } & $\mathrm{Cm}_{\mathrm{m}}^{244}$ \\
\hline$\underset{(\mathrm{pH} 4-5)}{\text { DISTILLED }}$ & & & & & $<10$ & 0 \\
\hline $\mathrm{HCl}$ & & & & & & \\
\hline IN & $<10$ & 0 & 58 & 0 & & \\
\hline $2 \mathrm{~N}$ & 7 & 0 & 94 & 0 & 0 & \\
\hline $3 N$ & 0 & 0 & 98 & 0 & & \\
\hline $4 N$ & 8 & 10 & 99 & 32 & 0 & 0 \\
\hline $6 \mathrm{~N}$ & & 33 & 100 & 19 & & \\
\hline $8 \mathrm{~N}$ & 0 & 95 & 100 & 39 & 0 & \\
\hline $\begin{array}{l}\mathrm{HNO}_{3} \\
4 \mathrm{~N}\end{array}$ & 46 & 20 & 66 & 73 & 0 & 0 \\
\hline
\end{tabular}

\section{URANIUM-235 ANALYSIS OF $150 \mathrm{mI}$ URINE}

1. WET OXIDATION

2. RESIDUE DISSOLUTION

$50 \mathrm{ml} 3.5 \mathrm{~N} \mathrm{HCl}$.

3. FIRST EXTRACTION

$50 \mathrm{ml}$ 10\% TIOA-XYLENE - 2 MINUTES.

4. SECOND EXTRACTION $25 \mathrm{ml}$ 10\% TIOA-XYLENE - 2 MINUTES.

5. WASH COMBINED TIOA (75 ml) WASHED WITH $15 \mathrm{ml} 3.5 \mathrm{~N} \mathrm{HCl} ; \mathrm{HCl}$ DISCARDED.

6. DESORPIION TWO 25-mI DISTILLED $\mathrm{H}_{2} \mathrm{O}$ WASHES OF

7. PLANCHET AND COUNT 
3. FOUR ACTINIDES EXTRACTED INTO $10 \%$ TIOA-XYLENE FOLLOWING TREATMENT WITH VARIOUS REAGENTS

\begin{tabular}{|c|c|c|c|c|c|}
\hline \multirow[b]{2}{*}{ REAGENT } & \multirow[b]{2}{*}{ SOLUTION } & \multicolumn{4}{|c|}{ PERCENT EXTRACTED } \\
\hline & & $\underline{T h}$ & $N p$ & $U$ & $\underline{P_{u}}$ \\
\hline AMMONIUM IODIDE & $\mathrm{CONC} \mathrm{HCl}$ & 35 & $>99$ & $>99$ & $<5$ \\
\hline FERROUS AMMONIUM SULFATE & $2 \mathrm{~N} \mathrm{HNO}_{3}$ & 59 & $<5$ & 22 & $>95$ \\
\hline FERROUS SULFAMATE & $4 \mathrm{~N} \mathrm{HNO}_{3}$ & 15 & $>95$ & 48 & $<3$ \\
\hline
\end{tabular}

\section{SIX ACTINIDES EXTRACTED INTO $20 \%$ HDEHP-TOLUENE}

\begin{tabular}{|c|c|c|c|c|c|c|}
\hline \multirow[b]{2}{*}{ AQUEOUS SOLUTION } & \multicolumn{6}{|c|}{ PERCENT EXTRACTED } \\
\hline & $\mathrm{Th}^{232}$ & $\mathrm{~Np}^{237}$ & $\underline{u}^{238}$ & $\mathrm{Pu}^{239}$ & $\mathrm{Am}^{241}$ & $\mathrm{Cm}^{244}$ \\
\hline DISTILLED $\mathrm{H}_{2} \mathrm{O}$ & & & & & & \\
\hline$(\mathrm{pH} \mathrm{4-5)}$ & 67 & 43 & 60 & 72 & $>99$ & $>99$ \\
\hline $\mathrm{HNO}_{3}$ & & & & & & \\
\hline $2 N$ & 35 & 66 & $>99$ & 97 & 0 & \\
\hline $4 N$ & 95 & 93 & $>99$ & 90 & 0 & 0 \\
\hline $8 \mathrm{~N}$ & 63 & 80 & 100 & 98 & 0 & \\
\hline $\mathrm{HCl}$ & & & & & & \\
\hline $2 \mathrm{~N}$ & 52 & 0 & $>99$ & 49 & 0 & \\
\hline
\end{tabular}




\section{AMERICIUM-CURIUM ANALYSIS OF $250 \mathrm{mI}$ URINE}

1. WET OXIDATION

2. RESIDUE DISSOLUTION

3. FIRST EXTRACTION

4. SECOND EXTRACTION

5. WASH

6. DESORPTION

7. PLANCHET AND COUNT
$50 \mathrm{ml} 4 \mathrm{~N} \quad \mathrm{HNO}_{3}$.

$20 \%$ HDEHP-TOLUENE; DISCARD HDEHP.

NEUTRALIZE AQUEOUS ABOVE WITH $\mathrm{NH}_{4} \mathrm{OH}_{\text {; EXTRACT WITH } 20 \% \text { HDEHP }}$ IN TOLUENE.

HDEHP WASHED WITH $15 \mathrm{ml}$ DISTILLED $\mathrm{H}_{2} \mathrm{O}$; WASH DISCARDED.

TWO $25-\mathrm{ml} 4 \mathrm{~N} \mathrm{HNO}_{3}$ WASHES OF HDEHP.

\section{6. $A M^{241}$ FROM OXIDIZED URINE SOLUTION} EXTRACTED INTO 20\% HDEHP-TOLUENE

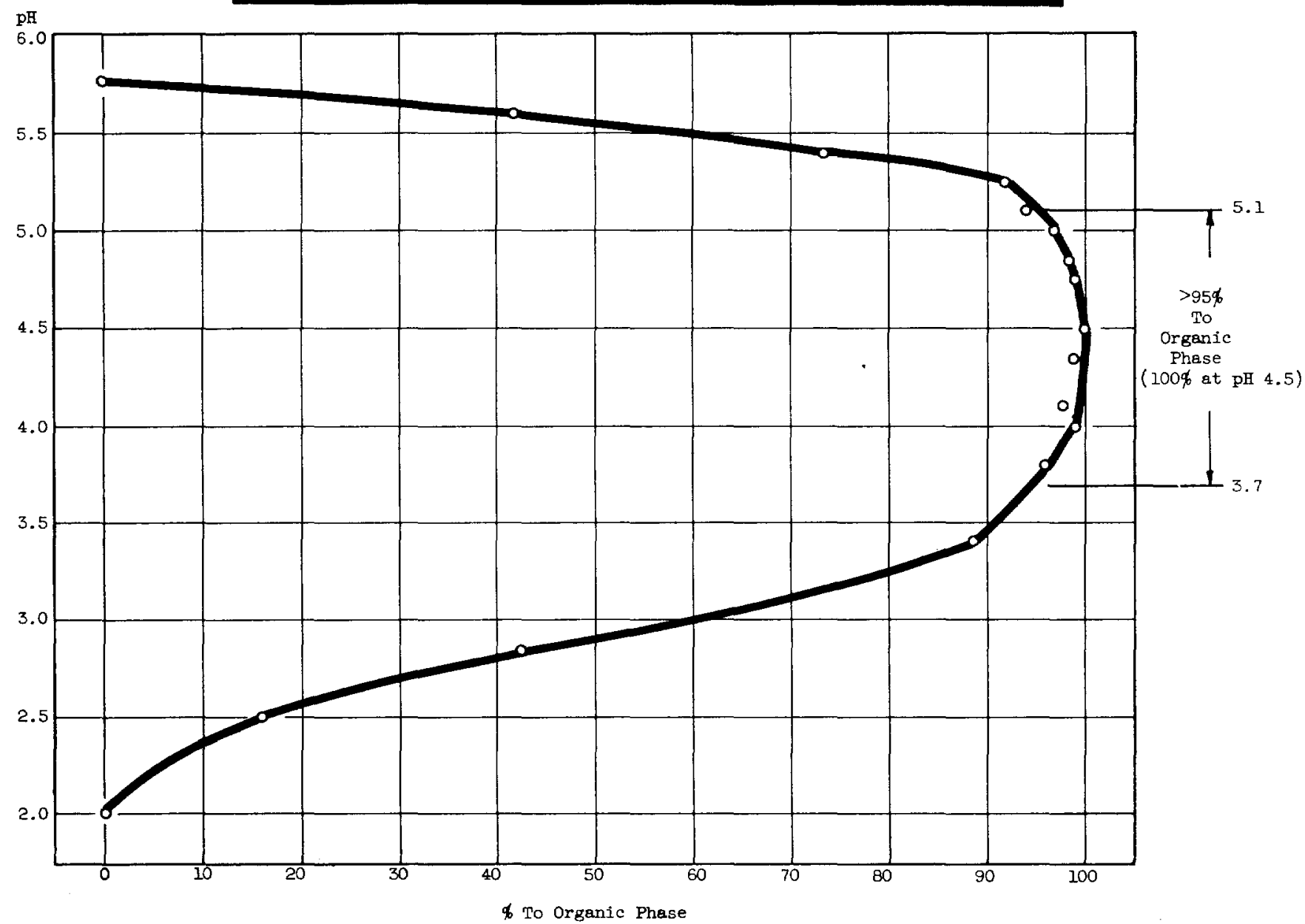

